\title{
Saving the African Heritage is a Global Priority: How Can a New Subdiscipline of Rescue Archaeology Aid It?
}

\author{
John Alexander
}

Published online: 22 March 2011

(C) Springer Science+Business Media, LLC 2011

"Heritage" is a terrible word for scholars, an omnibus term which includes all that individuals and communities accept of their past with affection and pride. At its widest and most romantic, they may well be prepared to kill or die for it. As Lord Macaulay wrote over a hundred years ago:

"And how can man die better

Than facing fearful odds,

For the ashes of his fathers,

And the temples of his Gods?"

[Thomas B. Macaulay, Lays of Ancient Rome. Horatius, xxvii, 1842]

Those who study the human past are well aware that all heritages are selective and change through time, and that in a great continent like Africa with many millennia of human history there has been, and still is, a plethora of local heritages. It is perhaps optimistic to expect common factors in all of them, but these may well exist and our role as scholars is to try and discover them. In this short editorial, I am concerned mainly with the threats to these multiple heritages on the continent and reiterate my earlier call for the strengthening of rescue archaeology in Africa (Alexander 1974).

The destruction of the African tangible and intangible heritage, now taking place without being recorded in many countries, will be a tragedy for the whole human species. This is not only because the evidence of archaeology, human genetics and physical anthropology confirms our species developed in Africa and then spread from it, but because it is only in Africa that there is an unbroken development of human culture from its earliest manifestations to its present sophistication. This has taken place, until the last three centuries, without major external migration and conquest affecting its interior regions. The significance of this relative cultural isolation is only now coming to be realised, depending as it does on Africa's size and

The author of this editorial passed away in August 2010.

J. Alexander $(\bowtie)$

St. John's College, Cambridge, UK

e-mail: sulas@cantab.net 
surrounding oceans (Mitchell 2005; Barham and Mitchell 2008). With exploitation of natural resources proving a major threat to the archaeological record, those with an interest in Africa's past must act quickly to preserve this unique record. It is to be hoped that this special issue will contribute to alerting institutions like UNESCO, the World Bank and the United Nations so that permission and financial help for major development projects include the requirement that evidence from the past is recorded before destruction.

The history of rescue archaeology has created very particular patterns of work on different continents. In the USA, the New Deal, which followed the 1928-1931 economic crisis, created schemes of federal restoration and natural resource exploitation which insisted on archaeological surveys and excavation before destruction. This bred two generations of methodologically skilled "salvage archaeologists," who have had a great influence worldwide (Baldwin 1966). In Europe, the World War of 1939-1945 devastated many areas and led to large-scale restoration, greater exploitation of natural resources and the further unrecorded destruction of evidence of the past (Alexander 1974). As this was realised, different European countries took different means, legal and financial, to avoid it. Some, as France, Germany and the USSR, followed the North American route of central (or federal) and local government financing while others like Great Britain chose increasingly strong legal controls linked to the planning stages of both government and commercial projects, and insisted that the developer should pay. This latter provision is absent in America (Rahtz 1974). It came to be called rescue archaeology and - as in the USA - led to the development of archaeological field units staffed by university-trained staff who were hired and paid by developers. These have continued to provide efficient and experienced teams until today. As a result, in Europe and North America the problems of unrecorded destruction have been largely solved. How this was achieved should be studied, but not copied, in Africa. A world review of Heritage Management (Cleere 1989) can also be recommended to all those concerned with current problems, even if Africa is little considered in it; only three of the 31 sections relate to Africa. It is, however, a point from which the present position can be reviewed.

In 1974, I advocated an extension of the "Developer Pays" principle to countries worldwide, as an effective means of ensuring the preservation of Africa's heritage (Alexander 1974). By the 1990s almost all of the African states had universities with archaeological departments or faculties, their graduates staffing national antiquities services. These administered the legal and physical defence of selected, usually aboveground, sites and with the formation of ICOMOS (1965, see Cleere 1989) the future seemed encouraging. Since then, there has been a further world event which has increased African differences: the great increase in populations and the increasing demand for new energy resources and raw materials in which Africa is rich. Their exploitation has rarely been controlled by strong legal codes or accompanied by an insistence on "Developer Pays" salvage archaeology. It has been partly mitigated by the increase in research projects initiated and financed by institutions outside Africa.

That rescue archaeology under different names became an international concern in the 1960s was due to UNESCO. Its 1950s appeal for support in saving evidence of world importance, which would be lost with the flooding of the Middle Nile 
floodplain by Lake Nasser in Egypt and Sudan, was answered by some 70 nations both by financial aid and expeditions. The 2008 conference in Aswan and subsequent publication of the results of the UNESCO project should provide a reassessment of its success and failures. It is clear, however, that rescue work over the whole continent cannot be supported in the same way, even if expatriate research projects are welcomed and shared in many countries. Only if, in each country, local archaeologists and ethnologists in universities and antiquities services understand and are enabled to carry out rescue work will evidence be recorded (Kankpeyeng et al. 2009). Rescue archaeology requires different skills, wider knowledge and a greater urgency than the study of unthreatened sites (Cleere 1989: 280-284). Its practitioners must be prepared to recognise and record evidence of all periods, to work closely with and understand the problems and constraints of contractors with penalty clauses for delays in their contracts, and must be willing to accommodate themselves to sudden changes of plan and swifter decision making than is usually required. They may well find themselves working with none but unskilled labour and restricted time and have to take decisions on the relative importance of their finds from different periods, realising that what they cannot save will be destroyed (Evans and Sorensen 2010). In Africa, as on other continents, only a few countries have so far succeeded in preparing their archaeologists for this kind of fieldwork.

Another problem is that, if the present African heritage is to be studied as having an unbroken unity with the past, there will be a need for a renewal of links with historians, linguists, and ethnologists (Iliffe 1995). These were more numerous in Africa when some aspects of the pre-European past could be studied through observations of living communities. Today, it means that the extensive museum and library collections of many countries throughout the world will need detailed reexamination of their African collections, both artefacts and ethnological studies. These should allow, it may be hoped, the wider understanding of the past demanded by those studying the "nontangible" heritage: historians, linguists, art historians, musicians, dancers and ethnomusicologists. Present-day heritages must all be considered as "selective heritages," as they are in all the continents and a new and potentially dangerous situation in Africa for the acceptance of its long heritage has been created by the nineteenth-century imperialism and twentieth-century independence. This led to the creation of new nationalities that may choose to see their heritage as linked only to the recent past or special parts of their earlier past. This will be strongest in intangible survivals - folklore, music, dancing, religion - and may lead to reluctance to accept more distant ancestors with distinct and much more fragile heritages.

One newly independent African country, Eritrea, has in the last decade put into practice many of the principles mentioned here and, with expatriate help, carried out and published the results (Schmidt et al. 2008 but pace Phillipson 2008). All Africanists will be interested in the important work published in Schmidt et al.'s volume, especially in Werede Okubay's chapter on the development of the tourism industry in Eritrea (Okubay 2008).

I have confined myself so far to considering the tangible evidence of the past recovered by archaeologists for I am not qualified to discuss the broader definitions of heritage which include the intangible. Evidence in Africa awaits discovery but much will be lost if the concept that "rescue archaeology" requires additional skills, 
and attitudes in those who undertake it are not explained and accepted. Many expatriate expeditions have these skills and can help, but on their own will not be sufficient to deal with the destruction. This will only be possible if the archaeologists in each African country accept and practice rescue archaeology. To do this, they will need the political policy makers of their own governments to insist that they appoint contractors to carry out surveys, excavations and publish them, or allow those employed by the government to do so. The governments themselves, it must be hoped, will be required to do this by international institutions financing projects. If this should happen, it could well be that from the existing pool of experienced rescue archaeologists in Europe, some could be recruited to teach it. In developing rescue archaeology on the continent, the support of the governments of African states will be essential. Efforts should also be made to bring together elected members of each African government who, whatever their political allegiances, are anxious to preserve their local heritages. The success in Britain of the All-Party Parliamentary Archaeological Group (APPAG ) which consists of some 120 members from both Houses of Parliament, should be seen as a model.

In conclusion, the choice of "fragile" to describe the African heritage is acceptable for it allows a certain degree of optimism to be expressed that the new heritages being created at present will be less narrowly selected and more tolerant than their predecessors.

\section{References}

Alexander, J. (1974). The world situation. In P. Rahtz (Ed.), Rescue archaeology (pp. 16-27). London: Harmsworth-Penguin.

Baldwin, G. (1966). Race against time: The story of salvage archaeology. New York: G.P. Putnam's Sons.

Barham, L., \& Mitchell, P. (2008). The first Africans. Cambridge: Cambridge University Press.

Cleere, H. (Ed.). (1989). Archaeological heritage management in the modern world. London: Unwin Hyman.

Evans, C. \& Sorensen, M.L. (2010) Citade Velha: Cape Verde Islands.

Iliffe, J. (1995). Africans, the history of a continent. Cambridge: Cambridge University Press.

Kankpeyeng, B., Insoll, T., \& MacLean, R. (2009). The tension between communities, development and archaeological heritage preservation: The case study of Tengzng Cultural Landscape, Ghana. Heritage Management, 2, 177-198.

Mitchell, P. (2005). African connections. Walnut Creek: Altamira Press.

Phillipson, D. W. (2008). Review: The archaeology of ancient Eritrea. Azania, 43, 152-158.

Rahtz, P. (Ed.). (1974). Rescue archaeology. London: Harmsworth-Penguin.

Schmidt, P. R., Curtis, M. C., \& Teka, Z. (Eds.). (2008). The archaeology of ancient Eritrea. Trenton: Red Sea Press.

Okubay, W. (2008). The role of ancient Ona sites in the development of the Eritrean tourism industry: An insider's perspective. In P. R. Schmidt, M. C. Curtis, \& Z. Teka (Eds.), The archaeology of ancient Eritrea (pp. 359-375). Trenton: Red Sea Press. 